\title{
EFFICIENCY OF MULTISENSORIC THERAPY IN AUTISM SPECTRUM DISORDER PATIENTS
}

\author{
Aleksandrs Vasil̨onoks ${ }^{1}$, Irisa Zïle ${ }^{2}$, and Valdis Folkmanis ${ }^{3, \#}$ \\ ${ }^{1}$ Children's Clinical University Hospital, 45 Vienïbas gatve, LV-1004, Rīga, LATVIA \\ ${ }^{2}$ Chair of Paediatrics, Faculty of Medicine, University of Latvia, 19 Raina Blvd. LV-1586, Rĩga, LATVIA \\ ${ }^{3}$ Centre of Social Pediatrics, Faculty of Medicine, University of Latvia, 19 Raiṇa Blvd. 19, LV-1586, Rīga, LATVIA \\ \# Corresponding author, valdis.folkmanis@lu.Iv
}

Communicated by Ingrīda Rumba-Rozenfelde

\begin{abstract}
The aim of this study was to investigate the role of various treatment methods for children with autistic spectrum disorders (ASD). The prospective study was conducted in 2013-2015 at the Children's University Hospital and Social Pediatric Centre of the University of Latvia. The data analysis included 72 children (2 to 5 year old) with ASD, of whom 38 had infantile autism, 16 had atypical autism, and 18 had other diffuse developmental disorder). $86.1 \%$ patients received therapy. The most common treatment was by Montessori method and special pedagogue. Other treatments were dance-movement therapy, animal, sand and one patient received spa treatments. Univariate OR analysis showed that Montessori therapy had a decreasing trend on three health disorders (visual, hearing, and fine motor skills disorders) compared with other types of therapy, but the effect was not statistically significant. Special pedagogue therapy for autism patients showed similar results. A significant effect was observed for fine motor skills $(p<0.05)$ and speech development $(\mathrm{p}<0.05)$, and Montessori method and special education were shown to be the most effective tools for promoting developmental progress and reducing developmental delay. Special pedagogue method showed statistically significant efficiency in fine motor skills and speech development. However, significant differences were not found for the Montessori method due to a limited number of patients.
\end{abstract}

Key words: autism, multisensory therapy, Montessori method, psychomotor development.

According to the World Centre for Disease Control, the frequency of symptoms of autism spectrum disorders in the period from 2000 to 2010 in Europe increased from $1: 150$ to $1: 68$ (Vasilonoks, 2016). In this regard, the question of the effectiveness of developmental therapy is important. Autism spectrum disorder affects a child's ability to acquire social skills. Effective treatment is necessary to facilitate development of all psychomotor skills. Recently, it has been shown that music therapy can improve social outcomes in children with autism disorders (Zwaigenbaum, 2005). Data published in 2017 suggest that metacognitive skills are associated with social functioning (LaGasse, 2017). Therefore, clarifying efficient intervention strategies has become very important for these children.

In 2013-2015, a prospective study was conducted with patients of the Children's Clinical University Hospital in Riga to determine benefits of specific types of therapy on psychomotor development of the child. The main hypothesis of the research was that special pedagogic education and the
Montessori method are effective treatment methods in autistic children.

Subjects and study design. During the period of 2013-2015, a prospective study was conducted at the Children's Clinical University Hospital and the Social Pediatric Centre of the University of Latvia to determine the effectiveness of treatment for children with autistic spectrum disorders. The study group was 72 children at age 2 to 5 years with Autism Spectrum Disorders. Of these, 38 were diagnosed with "infantile autism", 16 - "atypical autism" and 18 with "other diffuse developmental disorder". Forty-eight children attended sessions with a special teacher, 24 attended teaching classes using the Montessori method, $14-$ sand therapy, 12 - water treatment, 12 - dance movement therapy and $9-$ Treatment of Animals $(3-$ dolphin therapy and $6-$ Reiter therapy). They were grouped according to their psychomotor ability by questionnaire evaluation using scales and the Munich Denver functional test. The groups were: 1) hearing perception disorders, 2) visual per- 
ceptual disorders, 3) language development disorders, 4) small motor disabilities, and 5) large motor development and daily operations. We involved also two control groups: 28 children without neurodevelopmental impairment and 10 children with a diagnosis of "autism" but not receiving any treatment.

The study consisted of three parts: 1) the parents of the child filled out a structured questionnaire based on the norms of psychomotor development at a certain age; 2) the ability and level of development was evaluated by doctors observing the child, using a similar questionnaire adapted from the Denver test of psychomotor development; and 3 ) the degree of psychomotor development was assessed by a psychiatrist and a clinical psychologist using the Munich scale physiological diagnosis (8).

Statistical analysis. The descriptive statistics for continuous variables are reported as median $\left(25^{\text {th }}\right.$ and $75^{\text {th }}$ percentile). The Chi-square test for comparing categorical variables was used. Categorical data are reported as percentages and $95 \%$ confidence interval (CI). The odds ratios (OR) and 95\% CI were computed to measure the therapy intervention. If the OR was $>1$ the control was better than the intervention but if the OR is $<1$ the intervention is better. In the univariate logistic regression analysis we compared two main treatments: the Montessori method and sessions with a special pedagogue.

Spearman rank correlation was used to measure the association between health disorders improvements after complex therapy.

The study was conducted in 2013-2015 in Riga. The total population was 72 patients with autism spectrum disorders. The mean age of the studied population was 4 years (3-5). Patients were divided in three categories: atypical autism $22.2 \%(\mathrm{n}=16)$, infantile autism $52.8 \%(\mathrm{n}=38)$ and other diffuse development disorders $25.0 \%(\mathrm{n}=18)$.

Compliance with the age norms was found only for two children $(5.3 \%)$, who had infantile autism.

$86.1 \%(n=62 / 72)$ patients received therapy. The most common was Montessori method $-41.9 \%(\mathrm{n}=26)$ and special pedagogue $33.9 \%(\mathrm{n}=21)$, followed by dance-movement therapy $11.3 \%(\mathrm{n}=7)$, animal $6.5 \%(\mathrm{n}=4)$, sand therapy $4.8 \%(\mathrm{n}=3)$, and one patient received spa treatments $1.6 \%$. The received therapy types differed between diseases groups $(\chi 2=38.9 ; p<0.001)$.

Classes with a teacher using the Montessori method involve not only development of games, but also mastering of skills every day. A special feature of the Montessori method is the development of thinking - the child chooses what he will do during class. In order for a child to choose less useful activity, the teacher can limit the range of action, propose actions or give specific assignments. Montessori training particularly contributes to the development of fine motor skills.
Using the abovementioned therapies for autism patients, we observed a positive statistically significant correlation between hearing improvement and speech development $(\mathrm{r}=$ $0.3 ; p=0.03$ ) and between visual improvement and gross motor skills improvement $(\mathrm{r}=0.3 ; p=0.05)$.

We analysed two treatment methods in detail, as they were the most commonly applied: Montessori and special pedagogue therapy. There were no statistically significant differences observed in health characteristic improvement by groups between Montessori and Special pedagogue therapy (Table 1). Nevertheless, improvement of was observed in more than half of the patients.

Table 1

COMPARISON OF HEALTH IMPROVEMENT OF AUTISM PATIENTS IN THE MONTESSORI AND SPECIAL PEDAGOUGE THERAPHY GROUPS

\begin{tabular}{l|c|c|c}
\hline \multirow{2}{*}{ Characteristics } & \multicolumn{3}{|c}{ Therapy method } \\
\cline { 2 - 4 } & Montessori*\% & $\begin{array}{c}\text { Special } \\
\text { pedagogue }, \%\end{array}$ & $p^{* *}$ \\
\hline Visual improvement & 53.8 & 52.4 & $p=0.942$ \\
Hearing improvement & $(34.8-72.1)$ & $(31.4-72.7)$ & \\
Fine motor skills & 50.0 & 52.4 & $p=0.871$ \\
improvement & $(31.3-68.7)$ & $(31.4-72.7)$ & \\
Gross motor skills & $(38.4-75.4)$ & $(49.8-87.5)$ & \\
improvement & 46.2 & 61.9 & $p=0.441$ \\
Speech development & $(27.9-65.2)$ & $(40.2-80.5)$ & \\
improvement & 19.2 & 47.6 & $p=0.302$ \\
& $(7.4-37.6)$ & $(27.3-68.6)$ &
\end{tabular}

* represents $\%(95 \% \mathrm{CI})$, calculated within therapy type group; ${ }^{* *}$ Chi square test was used

Univariate OR analysis showed that Montessori therapy had a decreasing trend on three health disorders (visual, hearing, and fine motor skills disorders), compared with other types of therapy but the effect was not statistically significant. An OR 1 indicated that the intervention therapy (Montessori or Special pedagogue) was better than other therapy methods. Special pedagogue therapy for autism patients showed similar results. This therapy had a preventive effect for all 5 health disorder groups. Fine motor skills $(\mathrm{OR}=0.3 ; p<$ $0.05)$ and speech development $(\mathrm{OR}=0.3 ; p<0.05)$ improved after special pedagogue therapy, compared with other types of treatment (Table 2).

Prospectively, the Montessori method gives good results for children education. In 2006, Sharlotville University (Virginia) published research results with healthy children. After attendance of Montessori classes, educational and academical ability improved by $60 \%$ in healthy children. Our study showed positive results also for autistic children. The Montessori method promotes progress in visual and auditory perception, and also motor skills. Most importantly, it improves socialisation skills. Another very important method to improve skills in patients with autism spectrum disorders was shown to be therapy with special pedagogue, as it significantly improved fine motor skills and speech 
Table 2

ODDS RATIOS FOR HEALTH IMPROVEMENT AMONG PATIENTS WITH AUTISM

\begin{tabular}{ll|c|c|c}
\hline \multicolumn{1}{c|}{ Characteristic } & \multicolumn{1}{c|}{ Therapy } & OR & 95\%CI & $p$ \\
\hline Visual improvement & Montessori & 0.4 & $0.1-1.1$ & 0.068 \\
& Special pedagogue & 0.5 & $0.2-1.4$ & 0.169 \\
Hearing improvement & Montessori & 0.8 & $0.3-2.2$ & 0.665 \\
& Special pedagogue & 0.7 & $0.2-2.0$ & 0.527 \\
Fine motor skills & Montessori & 0.7 & $0.2-1.8$ & 0.416 \\
improvement & Special pedagogue & 0.3 & $0.1-0.9$ & $0.029^{*}$ \\
Gross motor skills & Montessori & 1.5 & $0.6-4.0$ & 0.398 \\
improvement & Special pedagogue & 0.4 & $0.2-1.1$ & 0.061 \\
Speech development & Montessori & 2.7 & $0.8-8.7$ & 0.103 \\
improvement & Special pedagogue & 0.3 & $0.1-0.9$ & $0.042 *$
\end{tabular}

* Odds ratios were based on univariate analysis; $p<0.05$

development. A family doctor (or neurologist) can evaluate skill improvement after multisensory therapy with medicaments. Drug therapy was not used in the present study, but this method has received the most interest in research. A large study (Rezaei et al., 2010) on the effect of topiramate treatment. However, research on multisensory therapy are limited, particularly regarding combination of multisensory and medicament therapy.

The study showed that the Montessori method and special education were the most effective tools for promoting developmental progress and reducing developmental delay.

The special pedagogue method showed statistically significant effect in improvement of fine motor skills and speech development, compared to other treatment methods. For the Montessori method, a significant difference was not found due to limited number of patients. The best effect can be achieved by a combination of several therapies.

\section{REFERENCES}

Anonymous (2014). Autism and Developmental Disabilities Monitoring Network surveillance year 2010 principal investigators. Prevalence of autism spectrum disorders - Autism and Developmental Disabilities Monitoring Network, 11 sites, United States, 2010. U.S. Center for Disease Control and Prevention (CDC). Morbid. Mort. Weekly Rep., 63 (SS02), 1-18.

Dawson, G., Osterling, J. (1997). Early intervention in autism. In: Guralnick, M. (Ed.). The Effectiveness of Early Intervention. Brookes, Baltimore, MD, pp. 307-326.

Folkmanis, V. (2009). Sociālās pediatrijas iespējas bērnu veselības un sociālās attīstības riska faktoru diagnostikā un korekcijā [Possibilities of social paediatrics in the diagnostics and correction of the risk Factors for children's health and social development]. Rumba-Rozenfelde, I. (Ed.). Bērnu slimību riska faktori [Risk Factors for Children's Diseases]. University of Latvia, Rīga, pp. 127-140.

Freeman, L. M., Locke, J., Rotheram-Fuller, E., Mandell, D. (2017). Brief report: Examining executive and social functioning in elementary-aged children with autism. J. Autism Dev. Disord., 47 (6), 1890-1895.

LaGasse, A. B. (2017). Social outcomes in children with autism spectrum disorder: A review of music therapy outcomes. Patient Related Outcome Measures, 8, 23-32.

Ospina, M. B., Seida, J. K., Clark, B., Karhaneh, M., Hartling, L., Tjosvold, L, Smith, V. (2008). Behavioral and developmental interventions for autism spectrum disorder: A clinical systematic review. PLOS ONE, 3 (11), $1-32$.

Prizant, B. M., Wetherby, A. M. (1998). Understanding the continuum of discrete-trial traditional behavioral to social-pragmatic developmental approaches in communication enhancement for young children with autism/PDD. Seminars Speech Lang., 19 (4), 329-353.

Prizant, B. M., Wetherby, A. M., Rubin, E., Laurent, A. C., Rydell, P. J. (2006). The SCERTS Model: Comprehensive Educational Approach for Children with Autism Spectrum Disorders. Brookes, Baltimore, MD. 744 pp.

Vasilonoks, A., Folkmanis, V., Artaeva, T., Shena, I. (2016). Developmental therapy capabilities in autistic spectrum disorders treatment [Василёнок, А., Фолкманис, В., Артаева, Т., Шена, И. Возможности развивающей терапии в лечении детей с нарушениями аутического спектра]. Russian Medical Journal [PMЖ], No. 6, 376-378 (in Russian).

Zwaigenbaum, L., Bryson, S., Rogers, T., Roberts, W., Brian, J., Szatmari, P. (2005). Behavioral manifestations of autism in the first year of life. Int. J. Dev. Neurosci., 23 (2), 143-152.

\section{MULTISENSORĀS TERAPIJAS PIELIETOJUMS UN EFEKTIVITĀTE BĒRNIEM AR AUTISKĀ SPEKTRA TRAUCĒJUMIEM}

Šì pētījuma mērkis bija noskaidrot dažādu terapijas metožu ārstēšanas efektivitāti bērniem ar autiskā spektra traucējumiem (AST). Analīzē tika iekḷauti 72 bērni ar AST (38 ar zīdaiṇu autismu; 16 ar netipisku autismu; 18 citi ar difūziem attīstības traucējumiem) (2-5 gadi). Pētījums tika veikts Bērnu klīniskajā universitātes slimnīcā sadarbībā ar Latvijas Universitātes Sociālās Pediatrijas centru (2013-2015). 86,1\% pacienti saṇēma terapiju. Visizplatītākā bija Montesori metode un "specializētais pedagogs", seko deju-kustību terapija, dzīvnieku, smilšu un tikai viens pacients saņēma ūdens terapiju. Izredžu attiecību (OR) vienfaktora analīze parādīja samazināšanās tendenci veselības traucējumiem trīs grupās (redzes, dzirdes un sīkā motorika) pēc Montesori terapijas salīdzinājumā ar citiem terapijas veidiem, bet nepierādījās kā statistiski nozīmīga. Saistībā ar "specializētā pedagoga" terapijas metodes pielietojumu AST pacientiem, tika novēroti līdz̄̄gi rezultāti, taču divās grupās tika novērota statistiskā ticamība: smalkai motorikai $(p<0,05)$ un runas attīstībai $(p<0,05)$. Montesori metode un speciālā izglītība pierādījās kā efektīvi terapijas instrumenti AST pacientu veselības traucējumu samazināšanai. Multisensorās terapijas pielietojums uzlabo bērnu psihomotoro attīstību un var kalpot kā efektīva metode darbā ar AST pacientiem. Rezultātu statistisko ticamību varēja ietekmēt nelielais pacientu skaits, ko nākotnē būtu nepieciešams palielināt, lai turpinātu pētījumu. 